\title{
MEAN SERUM FERRITIN LEVELS IN TYPE-2 DIABETES MELLITUS IN PAKISTANI POPULATION
}

\author{
Kamran Ali, Qasim Raza*, Tarique Ahmed Maka**
}

66 Medical Battalion/National University of Medical Sciences (NUMS) Pakistan, *Quaid-e-Azam International Hospital, Islamabad Pakistan, ${ }^{* *}$ Combined Military Hospital Risalpur/National University of Medical Sciences (NUMS) Pakistan

\section{ABSTRACT}

Objective: To evaluate the mean serum ferritin in type-2 diabetic patients.

Study Design: Cross-sectional study.

Place and Duration of Study: Department of Medicine, Combined Military Hospital, Peshawar, from Sep 2014 to Feb 2015.

Methodology: A total of one hundred patients with type-2 diabetes mellitus fulfilling inclusion criteria were selected. Blood sample was collected from all patients by the clean-catch technique after they received standardized verbal instructions. Blood samples were seen by classified pathologist in the laboratory.

Results: Mean age of patients was $55.51 \pm 5.40$ years with $60 \%$ male gender predominating the overall sample of diabetics. Mean serum ferritin was $219 \pm 70.67 \mathrm{ng} / \mathrm{ml}$ and mean HbA1c was $7.24 \pm 0.61 \%$. Stratification with regard to age and gender was also carried out.

Conclusion: Serum ferritin levels were observed raised in type-2 diabetics, suggestive of possible role in the pathogenesis of type-2 diabetes mellitus. We recommend further research work over its pathogenesis so that the guidelines for its control may be formulated.

Keywords: HbA1c, Serum ferritin, Type-2 diabetes mellitus.

This is an Open Access article distributed under the terms of the Creative Commons Attribution License (http://creativecommons.org/licenses/by/4.0), which permits unrestricted use, distribution, and reproduction in any medium, provided the original work is properly cited.

\section{INTRODUCTION}

Diabetes mellitus (DM) is an endocrine disease that mainly affects metabolism causing abnormal glucose homeostasis ${ }^{1}$. Globally more than 171 million people are affected by diabetes mellitus ${ }^{2}$. Jayawardena et al in their systemic review expressed burden of diabetes mellitus ranging from $3 \%$ to $7.2 \%$ in a general population of Pakistan $^{3}$. Type 2 diabetes mellitus is 4 to 6 fold more prevalent in South Asians when compared to European individuals 4 .

Glycated hemoglobin or glycosylated hemoglobin $(\mathrm{HbA1c})$ is a form of hemoglobin that is used to measure regular plasma glucose meditation over extended periods of time. It is bent in a non-enzymatic glycation trail by hemoglobin's acquaintance to plasma glucose, which serves as a marker for regular blood glucose levels over the past three months prior to the measurement ${ }^{3}$.

Correspondence: Dr Kamran Ali, Graded Medical Specialist, Combined Military Hospital, Hyderabad Pakistan

Received: 02 May 2019; revised received: 04 Oct 2019; accepted: 17 Oct 2019
Serum ferritin is measured primarily to identify an index for body iron stores and this pointedly greater than before as period of diabetes mellitus increased. Elevated serum ferritin level is associated with higher risk of developing DM and the new onset of disease may be predicted by raised serum ferritin levels ${ }^{4,5}$. Sharifi et al their research work have exhibited the mean ferritin levels significantly greater in diabetics $101 \pm 73 \mathrm{mg} / \mathrm{ml}$ as compared to the control group $43.5 \pm 42 \mathrm{mg} / \mathrm{ml}$, $(p<0.001)^{6}$.

Raised iron stores of the body may plausibly cause diabetes by various established mechanisms, including oxidative stress induced cellular injury to the beta cells of the pancreas, suppression of insulin mediated glucose metabolism in the liver cells and diminishing of hepatic insulin abstraction by the liver 5,7 . Different studies in the past few years revealed that subclinical hemochromatosis and raised iron levels of the body has been positively linked with the impaired glucose tolerance and worsening of diabetic complications such as retinopathy, nephropathy and 
neurovascular dysfunction. A study conducted by Raj et al showed considerably positive correlation between serum ferritin level to the duration of diabetes, fasting blood sugar and $\mathrm{HbA}_{1} \mathrm{c}^{8}$.

Raised ferritin level is found to be one of the causative factor in the pathogenesis of type-2 DM. The data from studies conducted of western populaces has shown a strong positive correlation between type-2 DM and the raised ferritin levels. In our country however, the data is scarce exploring the correlation between type-2 DM and raised serum ferritin levels. The rationale of current study is to conclude association between serum ferritin levels and value of $\mathrm{HbA1c}$ in type$2 \mathrm{DM}$.

\section{METHODOLOGY}

The current project design was cross sectional study which carried out in the department of Medicine, Combined Military Hospital, Peshawar (Pakistan) from Sep 2014 to Feb 2015 after approval by the hospital ethical committee. Sample size was calculated using WHO calculator for sample size determination in health studies keeping confidence level $=95 \%$, population mean $=101$, standard deviation $=73$, absolute precision $=0.15^{7}$. A total number of one hundred patients, age ranging 40-65 years of both the sexes with type-2 DM were selected form outpatient and inpatient department through Non-probability consecutive sampling. Exclusion criteria were; patients suffering from chronic medical conditions like CKD, CLD, patients with history of hemoglobinopathy or hemochromatosis, patients receiving recurrent blood transfusions and corticosteroid or iron therapy.

Written informed consent, demographic data and history was taken from the patients. Detailed clinical examination focusing on onset and duration of diabetes mellitus and various micro \& macro vascular complications was carried out on each patient. Blood sampling done by catch technique and sent to laboratory where they were seen by classified pathologist.

Descriptive Statistical data was analyzed by IBM (International Business Machine) SPSS ver- sion 17. Quantitative variables like age, $\mathrm{HbA1c}$ and serum ferritin level were expressed as Mean and standard deviation (mean \pm SD). Qualitative variables like gender were presented as frequency and percentage. Stratification done to control effect modifiers like age and gender. To analyze the data Post-stratification independent sample t-test was used. A $p$-value $<0.05$ was considered statistically significant.

\section{RESULTS}

The mean age of the patients was $55.51 \pm 5.40$ years (table-I). Out of 100 patients, 60 patients $(60.0 \%)$ were males while 40 patients $(40.0 \%)$ were females (table-I). Analysis of results showed that the mean serum ferritin level was significantly increased $219 \pm 70.67 \mathrm{ng} / \mathrm{ml}$ and mean $\mathrm{HbA} 1 \mathrm{c}$ was $7.24 \pm 0.61 \%$ (table-II). Stratification with regard to age and gender presented in tables-III.

Table-I: Age \& Gender wise distribution of patients.

\begin{tabular}{|c|c|c|}
\hline Variable & n (\%) & Mean $\pm S D$ \\
\hline \multicolumn{3}{|c|}{ Age (Year) } \\
\hline $\begin{array}{l}40-50 \\
51-65\end{array}$ & $\begin{array}{l}20(20) \\
80(80)\end{array}$ & $55.51 \pm 5.40$ \\
\hline \multicolumn{3}{|l|}{ Gender } \\
\hline $\begin{array}{l}\text { Male } \\
\text { Female }\end{array}$ & $\begin{array}{l}60(60.0) \\
40(40.0)\end{array}$ & - \\
\hline
\end{tabular}

Table-II: Mean values of serum ferritin and HbA1c.

\begin{tabular}{l|c}
\hline Variables & Mean \pm SD \\
\hline Serum Ferritin $(\mathrm{ng} / \mathrm{ml})$ & $219 \pm 70.67$ \\
\hline HbA1c & $7.24 \pm 0.61$ \\
\hline
\end{tabular}

Table-III: Stratification with regard to age \& gender.

\begin{tabular}{|c|c|c|}
\hline Variable & $\begin{array}{l}\text { Serum Ferritin level } \\
(\mathrm{ng} / \mathrm{ml})(\text { Mean } \pm \text { SD) }\end{array}$ & $p$-value \\
\hline \multicolumn{3}{|c|}{ Age (Year) } \\
\hline $\begin{array}{l}40-50 \\
51-65\end{array}$ & $\begin{array}{l}191.75 \pm 79.89 \\
225.81 \pm 67.00\end{array}$ & 0.053 \\
\hline \multicolumn{3}{|l|}{ Gender } \\
\hline $\begin{array}{l}\text { Male } \\
\text { Female }\end{array}$ & $\begin{array}{l}271.48 \pm 30.27 \\
140.28 \pm 26.45\end{array}$ & $<0.001$ \\
\hline
\end{tabular}

\section{DISCUSSION}

Type-2 Diabetes mellitus is a global health problem and one of the common prevalent metabolic syndrome which is affecting great number 
of population worldwide. It is the disease of middle to old age individuals and more common than other variant of diabetes i.e type 1DM. The pathophysiology of T2DM is less well understood however, its slowly progressive disease and most of the times the individual affected remain asymptomatic for quite long time before proper diagnosis. Insulin resistance and beta cell defects are the hallmark of overt DM.

The likehood of the linkage between raised iron stores of the body and T2DM was first considered by Kay et al in their study which earned attention of researchers towards further exploring the subject ${ }^{9}$. A study conducted by Ford et al on United States population in 1999 has concluded raised levels of serum ferritin in the patients of T2DM as compared to the standard. However the authors apparently did not find clear cut role of raised irons stores of the body and damage to the beta cells of pancreas and insulin resistance ${ }^{10}$. The published literature showing varied opinion of the authors regarding role of serum ferritin in the pathogenesis of T2DM. Some authors has considered subclinical hemachromatosis as a cause of pancreatic beta cell destruction which subsequently leads to the development of T2DM whereas others determined it as an indication of pancreatic inflammation only without any overt damage to the beta cells. However, some authors have stated it a valid marker of insulin resistance.

Total body iron stores is proportionally related to serum ferritin concentration and is predisposed by several diseases. Raised serum ferritin level in non-pathologic disorders, reproducing subclinical iron excess, have been described to be related with insulin resistance and higher risk of T2DM ${ }^{12}$. Though, serum ferritin concentrations vary considerably according race, sex and region; and data analysis regarding the co-relation between glucose metabolism abnormalities and serum ferritin level in Asian population are at variance ${ }^{13}$.

Batchuluun et al conducted a study to compare serum ferritin levels between control group and patients of T2DM. The authors observed $43.4 \%$ of the T2DM patients were having elevated serum ferritin levels whereas only $21.2 \%$ control non-diabetics were having elevated serum ferritin levels. Their results revealed significantly ( $p$ $<0.001$ ) raised level of serum ferritin in T2DM group of patients as compared to the control nondiabetics. In this study the authors also found greater variance of serum ferritin levels in type 2 diabetic females with poor glycemic control. Those female patients in which $\mathrm{HbA1c}$ was equal to or greater than $7 \%$ have shown considerably greater elevated serum ferritin levels as compared to those whose $\mathrm{HbA} 1 \mathrm{c}$ was less than $7 \%{ }^{14}$.

Greater possibility of overt hyper-ferritinaemia is expected to be present in old age patients (>55 years) with uncontrolled T2DM. Therefore consistent monitoring of serum ferritin would be of significant value for anticipation and timely intervention to prevent development of T2DM among those who are at risk ${ }^{15}$. Emerging indications have mentioned a solid link between complications of T2DM and elevated iron stores of the body in general population. Our results are consistent with a study carried out by Raj et al that showed $54.3 \pm 9.2$ years mean age of patients with T2DM where as it was $55.51 \pm 5.40$ years in our study. They also revealed considerably higher serum ferritin in the cases $(p<0.001)$ of T2DM as compared to controls, likewise serum ferritin was considerably elevated in diabetic patients in our study $(p<0.001)$. These results have also been validated by Yeap et $a l^{16}$ and Zhan et al17. They concluded positive correlation between elevated serum ferritin levels and risk of developing DM and higher levels of $\mathrm{HbA} 1 \mathrm{c}^{14}$.

A research carried out at genetic level by Kwant et al to find out possible link between hemochromatosis and T2DM revealed that the higher incidence of $\mathrm{C} 282 \mathrm{Y}$ mutation of hemochromatosis gene is seen among the patients of T2DM, which could be the plausible mechanism of association between these two disorders. One more study conducted by Fernandez et al to find out correlation between insulin resistance and glucose tolerance with elevated serum ferritin 
levels among healthy individuals. They found positive correlation between impaired glucose tolerance and insulin resistance with elevated serum ferritin levels. Kim et al also showed such results in study. They recommend that elevated serum ferritin may be considered an independent factor of poor glycemic control in T2DM patients, however our local data lacking to confirm this recommendation. The incidence of prolonged micro and macro vascular complications of T2DM may be plausibly correlated to the elevated serum ferritin levels. In our study, mean serum ferritin was observed $219.00 \pm 70.67 \mathrm{ng} /$ $\mathrm{ml}$. We also observed that old age (>55 years) non-diabetics are at risk of elevated serum ferritin level.

\section{CONCLUSION}

In conclusion, raised level of serum ferritin is related to an increased incidence of T2DM. Consequently, the serum ferritin may possibly have a significant role in the pathogenesis of T2DM. Routine estimation of serum ferritin among all T2DM patients and setting a borderline serum ferritin level as an indicator of good glycemic control remain matter of debate. Further studies are recommended for setting up specific guidelines.

\section{CONFLICT OF INTEREST}

This study has no conflict of interest to be declared by any author.

\section{REFERENCES}

1. World Health Organization. Non communicable diseases. Fact sheet. Updated January 2015. Available from URL: http:// www.who.int/mediacentre/factsheets/fs355/en/.

2. Ramachandran A, Snehalatha C, Shetty AS, Nanditha A. Trends in prevalence of diabetes in Asian countries. World J Diabetes 2012; 15(1): 110-17.
3. Jayawardena R, Ranasinghe P, Byrne NM, Soares MJ, Katulanda $P$, HillsAP. Prevalence and trends of the diabetes epidemic in South Asia: a systematic review and meta-analysis. BMC Public Health 2012; 12(1): 380.

4. Hakeem R, Fawwad A. Diabetes in Pakistan: epidemiology, determinants and prevention. J Diabetol 2010;3(1): 1-13.

5. Knaebel J, Irvin BR, Xie CZ. Accuracy and clinical utility of a point-of-care HbA1c testing device. Postgrad Med 2013; 125(1): 91-98.

6. Sharifi F, Sazandeh S. Serum ferritin in type 2 diabetes mellitus and its relationship with HbA1c. Acta Medica Iranica 2004; 42(1): 142-45.

7. Orban E, Schwab S, Thorand B, Huth C. Association of iron indices and type 2 diabetes: a meta-analysis of observational studies. Diabetes Metab Res Rev 2014; 30(1): 372-94.

8. Raj S, Rajan G. Correlation between elevated serum ferritin and HbA1c in type 2 diabetes mellitus. Int J Res Med Sci 2013; 1(1): 12-15.

9. Kay M, Guay AT, Simonson DC. Non-insulin dependent diabetes mellitus and elevated serum ferritin level. J Diabetes Complications 1993; 7(4): 246-49.

10. Ford ES. Diabetes mellitus and serum ferritin concentration among USA adults. Diabetes Care 1999; 22(1): 1978-81.

11. Chen SCC, Huang YF, Wang JD. Hyperferritinemia and hyperuricemia may be associated with liver function abnormality in obese adolescents. PloS One 2012; 7(10): 8645.

12. Powers AC. Diabetes Mellitus. In: Harrison's principles of internal medicine. $18^{\text {th }}$ ed. Mc Graw Hill 2012; 2972-74.

13. Kim CH, Kim HK, Bae SJ, Park JY, Lee KU. Association of elevated serum ferritin concentration with insulin resistance and impaired glucose metabolism in Korean men and women. Metabolism 2011; 60(1): 414-20.

14. Batchuluun B, Matsumata T, Batchuluun B, Erdenebileg N, Tsagaantsooj G, Boldbaatar K, et al. Serum ferritin level is higher in poorly controlled patients with type 2 diabetes and people without diabetes, aged over 55 years. Diabet Med 2014; 31(4): 419-24.

15. Momeni A, Behradmanesh MS, Kheiri S, Abasi F. Serum ferritin has correlation with $\mathrm{HbA1c}$ in type 2 diabetic patients. Adv Biomed Res 2015; 4(1): 74.

16. Yeap BB, Divitini ML, Gunton JE, Olynyk JK, Beilby JP, McQuillan B, Hung J, Knuiman MW. Higher ferritin levels, but not serum iron or transferrin saturation, are associated with Type 2 diabetes mellitus in adult men and women free of genetic haemochromatosis. Clin Endocrinol 2015; 82(2): 525-32.

17. Zhan Y, Tang Z, Yu J. Serum ferritin, diabetes, diabetes control, and insulin resistance. Acta Diabetol 2014; 51(6): 991-98.

18. Kunutsor SK, Apekey TA, Walley J, Kain K. Ferritin levels and risk of type 2 diabetes mellitus: an updated systematic review and meta-analysis of prospective evidence. Diabetes Metab Res Rev 2013; 29(4): 308-18. 